\title{
Radionuclide wiggle matching reveals a nonsynchronous early Holocene climate oscillation in Greenland and western Europe around a grand solar minimum
}

\author{
Florian Mekhaldi ${ }^{1}$, Markus Czymzik ${ }^{2}$, Florian Adolphi ${ }^{1,3}$, Jesper Sjolte ${ }^{1}$, Svante Björck ${ }^{1}$, Ala Aldahan ${ }^{4}$, \\ Achim Brauer ${ }^{5}$, Celia Martin-Puertas ${ }^{6}$, Göran Possnert ${ }^{7}$, and Raimund Muscheler ${ }^{1}$ \\ ${ }^{1}$ Department of Geology - Quaternary Sciences, Lund University, 22362 Lund, Sweden \\ ${ }^{2}$ Leibniz Institute for Baltic Sea Research Warnemünde (IOW), Marine Geology, 18119 Rostock, Germany \\ ${ }^{3}$ Physics Institute, Climate and Environmental Physics \& Oeschger Centre for Climate Change Research, \\ University of Bern, 3012 Bern, Switzerland \\ ${ }^{4}$ Department of Geology, United Arab Emirates University, 15551 Al Ain, UAE \\ ${ }^{5}$ GFZ German Research Centre for Geosciences, Climate Dynamics and Landscape Evolution, 14473 Potsdam, Germany \\ ${ }^{6}$ Department of Geography, Royal Holloway University of London, Egham, TW20 0EX Surrey, UK \\ ${ }^{7}$ Tandem Laboratory, Uppsala University, 75120 Uppsala, Sweden
}

Correspondence: Florian Mekhaldi (florian.mekhaldi@geol.lu.se)

Received: 9 October 2019 - Discussion started: 4 November 2019

Revised: 24 May 2020 - Accepted: 3 June 2020 - Published: 3 July 2020

\begin{abstract}
Several climate oscillations have been reported from the early Holocene superepoch, the best known of which is the Preboreal oscillation (PBO). It is still unclear how the PBO and the number of climate oscillations observed in Greenland ice cores and European terrestrial records are related to one another. This is mainly due to uncertainties in the chronologies of the records. Here, we present new, high-resolution ${ }^{10} \mathrm{Be}$ concentration data from the varved Meerfelder Maar sediment record in Germany, spanning the period 11310-11000 years BP. These new data allow us to synchronize this well-studied record, as well as Greenland ice core records, with the IntCal13 timescale via radionuclide wiggle matching. In doing so, we show that the climate oscillations identified in Greenland and Europe between 11450 and 11000 years BP were not synchronous but terminated and began, respectively, with the onset of a grand solar minimum. A similar spatial anomaly pattern is found in a number of modeling studies on solar forcing of climate in the North Atlantic region. We further postulate that freshwater delivery to the North Atlantic would have had the potential to amplify solar forcing through a slowdown of the Atlantic meridional overturning circulation (AMOC) reinforcing surface air temperature anomalies in the region.
\end{abstract}

\section{Introduction}

One of the great challenges in paleoclimatology today is how to better assess the spatial and temporal dynamics of past climate changes. This can only be achieved through robust and consistent chronologies for different records and different regions. Unfortunately, this is a challenging task, and we often assume the synchrony of such events through climate tuning different records. One such example is the Preboreal oscillation (PBO) (Björck et al., 1996), which represents a cold spell that occurred shortly after the Younger Dryas-Holocene transition. Indications of a cold phase have also been reported in a number of European terrestrial records, most of which use biological proxy and isotope data (Björck et al., 1996, 1997; Bos et al., 2007; Magny et al., 2007; van der Plicht et al., 2004; von Grafenstein et al., 1999). A cold and dry climate oscillation, thought to be related to the European PBO, has also been observed in the $\delta^{18} \mathrm{O}$ and accumulation signals of a number of Greenland ice cores between 11520 and 11400 years before $2000 \mathrm{CE}$ (b2k), and it is referred to as the $11.4 \mathrm{ka}$ event (Rasmussen et al., 2007, 2014). Due to chronological uncertainties, it is, however, unclear whether the $11.4 \mathrm{ka}$ event in Greenland and the European PBO represent one single and synchronous widespread event, an event 
that gradually propagated over time, or whether the European PBO is unrelated to the $11.4 \mathrm{ka}$ event in Greenland. These open questions limit our understanding of the underlying triggering and propagation mechanisms of these climate changes.

Around this period, one of the largest and longest-lasting grand solar minima (persistently low solar activity resulting in a significantly higher radionuclide production rate) of the Holocene occurred between 11280 and 10960 years before $1950 \mathrm{CE}$ (BP). This was evidenced by beryllium-10 $\left({ }^{10} \mathrm{Be}\right)$ data in the Greenland Ice Core Project ice cores (GISP2 and GRIP) in central Greenland (Finkel and Nishiizumi, 1997; Muscheler et al., 2004; Adolphi et al., 2014) and by $\Delta^{14} \mathrm{C}$ $\left({ }^{14} \mathrm{C} /{ }^{12} \mathrm{C}\right.$ corrected for fractionation and decay relative to a standard and noted as $\Delta$ in Stuiver and Polach, 1977) derived from tree rings (Reimer et al., 2013). This substantial change in solar activity (from high to persistently low) offers an advantage to us for synchronizing timescales as it has left a clear imprint on the atmospheric production rate of the cosmogenic radionuclides ${ }^{10} \mathrm{Be}$ and ${ }^{14} \mathrm{C}$ (Fig. 1). That is to say that these radionuclides are produced by a nuclear cascade which is triggered when cosmic rays enter the atmosphere. The Earth is shielded, to some extent, from these cosmic rays by the fluctuating strength of the helio- and geomagnetic fields. Therefore, radionuclides carry in part the signal of solar activity, which is then stored in natural archives such as in polar ice caps or lake sediments $\left({ }^{10} \mathrm{Be}\right)$, as well as in tree rings $\left({ }^{14} \mathrm{C}\right)$. Consequently, we can use these global fluctuations in the atmospheric production rate of radionuclides to synchronize records from different environmental archives and investigate the timing of climate events during the earliest part of the Holocene (Southon, 2002; Muscheler et al., 2014; Adolphi and Muscheler, 2016).

Here we present new, high-resolution ${ }^{10} \mathrm{Be}$ concentration measurements from the well-studied varved Meerfelder Maar (MFM) sediment record in western Germany, spanning across these large fluctuations in solar activity from 11310 to 11000 years BP. Because of its limited catchment area and the existence of ${ }^{10} \mathrm{Be}$ data covering the late glacial-Holocene transition (Czymzik et al., 2016), MFM represents an ideal location for the aim of this study. As such, the new ${ }^{10} \mathrm{Be}$ data allow us to synchronize MFM and Greenland ice core records with the IntCal13 timescale through the wiggle matching of these different radionuclide records. We can then investigate the timing of the fluctuations observed in the corresponding paleoclimate records at a high chronological precision and assess their relationship in regard to changes in solar activity.

\section{Methods}

\subsection{Preparation of sediment ${ }^{10} \mathrm{Be}$ samples}

The new ${ }^{10} \mathrm{Be}$ samples come from the composite sediment profile MFM09 (Martin-Puertas et al., 2012a) which was retrieved at MFM, a deep crater lake situated in the Eifel region of western Germany that was annually laminated (varved) throughout most of the Holocene (Brauer et al., 2000). Around $0.25 \mathrm{~g}$ of dried and crushed material was taken for each sample with a temporal resolution of 3 and 10 years (see dataset), and $0.5 \mathrm{mg}$ of ${ }^{9} \mathrm{Be}$ carrier was added. ${ }^{10} \mathrm{Be}$ was extracted from the sediment samples at the ${ }^{10} \mathrm{Be}$ laboratory of the Earth Sciences Department of Uppsala University, Sweden, following the methodology described by Berggren et al. (2010). All samples were measured using the accelerator mass spectrometer (AMS) of the Tandem Laboratory in Uppsala. The ${ }^{10} \mathrm{Be}$ concentration (in atoms per gram) of each sample is calculated based on the ${ }^{10} \mathrm{Be}$ counts $R$ to ${ }^{9} \mathrm{Be}$ counts Rst ratio and, taking into consideration the NIST SRM 4325 reference standard $\left({ }^{10} \mathrm{Be} /{ }^{9} \mathrm{Be}=2.68 \times 10^{-11}\right)$, on the weights of the carrier $W_{\mathrm{C}}$ and of the sample $W_{\mathrm{S}}$, as well as the Avogadro constant $N_{\mathrm{A}}$ and atomic weight $A_{\mathrm{r}}$ of beryllium:

${ }^{10}$ Be conc. $=\frac{R}{R_{\mathrm{st}}} \cdot 2.68 \times 10^{-11} \cdot \frac{W_{\mathrm{C}}}{W_{\mathrm{S}}} \cdot \frac{N_{\mathrm{A}}}{A_{\mathrm{r}}}$.

\subsection{Chronologies and synchronization}

The paleoclimate data investigated herein come from different studies with different records and thus different chronologies. The new sediment ${ }^{10} \mathrm{Be}$ concentration data come from MFM, the chronology of which (MFM2012) was established using mainly microscopic varve counting fixed on an absolute timescale via tephrochronology, as well as radiocarbon dating, with a maximum varve counting error of up to 110 years (Brauer et al., 2000; Martin-Puertas et al., 2012a). A more recent chronology (MFM2015) exists which includes the identification and age of the Vedde Ash, although it remains unchanged for the Holocene part (Lane et al., 2015), which is the period of focus in this study. We also use published ${ }^{10} \mathrm{Be}$ flux data (Adolphi et al., 2014) from the GRIP ice core in central Greenland and within the Greenland Ice Core Chronology 2005 (GICC05) framework (Rasmussen et al., 2006; Vinther et al., 2006; Svensson et al., 2008; Seierstad et al., 2014). Finally, we use ${ }^{14} \mathrm{C}$ production rate data (Muscheler et al., 2014) inferred from the IntCal13 ${ }^{14} \mathrm{C}$ calibration curve (Reimer et al., 2013) as the anchoring record for our synchronization. That is to say that we synchronize the MFM2012 timescale (using our ${ }^{10} \mathrm{Be}$ concentration data) and the GICC05 timescale (using the GRIP ${ }^{10} \mathrm{Be}$ flux data) with IntCal13 (using the ${ }^{14} \mathrm{C}$ production rate data).

The synchronization of the different radionuclide records was computed following the methodology described in Adolphi and Muscheler (2016). This method employs the same Bayesian approach as is used for wiggle matching tree ring ${ }^{14} \mathrm{C}$ sequences to the radiocarbon calibration curve (Bronk Ramsey et al., 2001). It exploits the fact that the spacing between samples is precisely known from varve and layer counts and that, hence, the probability density functions from individual samples can be combined using Bayes' theorem. Analogous to radiocarbon wiggle matching of tree rings, we 


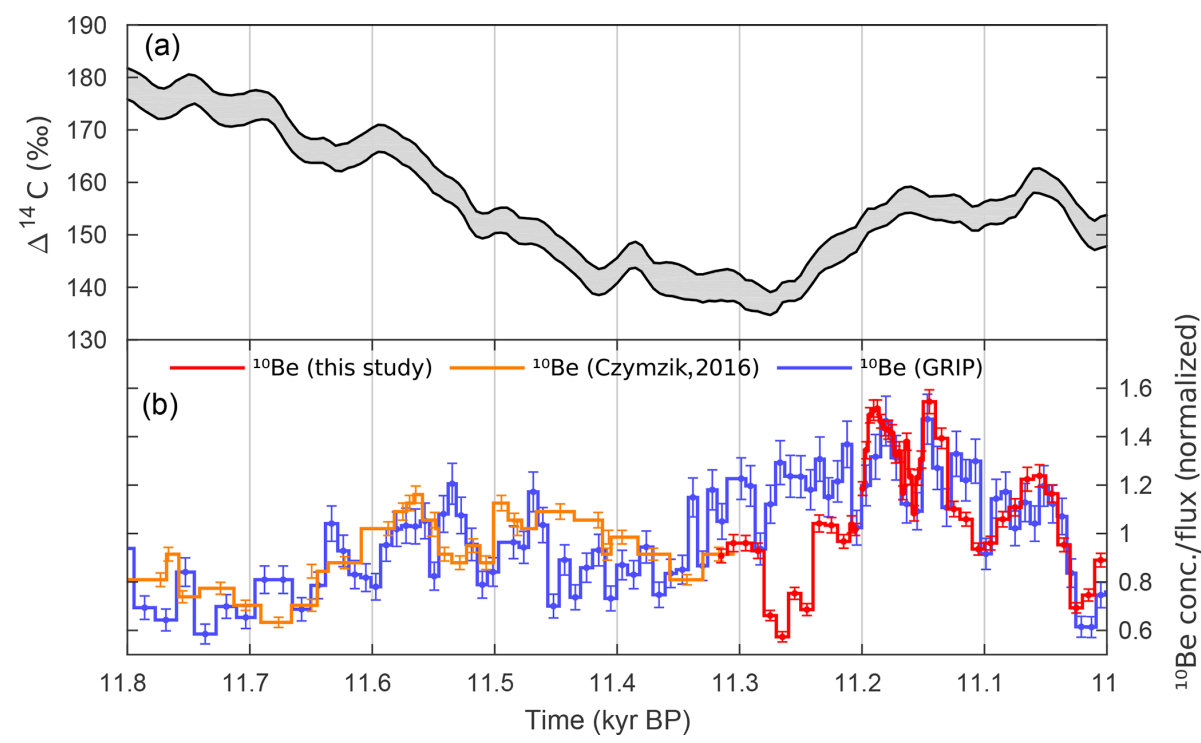

Figure 1. (a) The IntCal13 calibration curve (Reimer et al., 2013) expressed as $\Delta^{14} \mathrm{C}$ (see text). (b) The ${ }^{10} \mathrm{Be}$ concentration data from Meerfelder Maar (MFM), spanning the period 11310-11000 years BP, are plotted in red with corresponding measurement error bars. The record is completed in orange with the ${ }^{10} \mathrm{Be}$ measurements from the same sediment profile for the late glacial-Holocene transition (Czymzik et al., 2016). The MFM ${ }^{10} \mathrm{Be}$ data are plotted on the original MFM2012 chronology. The ${ }^{10} \mathrm{Be}$ flux data from the GRIP ice core in central Greenland (Adolphi et al., 2014) are plotted in blue and on the GICC05 timescale (Rasmussen et al., 2006; Vinther et al., 2006; Svensson et al., 2008; Seierstad et al., 2014). All records have been normalized to their mean.

use one record (for example ${ }^{14} \mathrm{C}$ production rate) as our "calibration curve", while the other record serves as our "tree rings" (e.g., MFM and GRIP ${ }^{10} \mathrm{Be}$ ). By shifting one relative to the other, we can thus estimate a probability density function of the timescale difference between the two records. Further details can be found in Adolphi and Muscheler (2016) and Bronk Ramsey et al. (2001). For these calculations, we linearly detrend all radionuclide records between 11800 and 11000 years BP and assume a production rate uncertainty of $20 \%$ for all records, which corresponds to the root mean square error between the records after synchronization.

\section{Results}

\subsection{Meerfelder Maar ${ }^{10} \mathrm{Be}$ concentrations}

The new ${ }^{10} \mathrm{Be}$ concentration measurements from MFM are displayed in Fig. 1 alongside ${ }^{10} \mathrm{Be}$ flux data from the GRIP ice core in central Greenland (Finkel and Nishiizumi, 1997; Muscheler et al., 2004; Adolphi et al., 2014) and older ${ }^{10} \mathrm{Be}$ concentration data from MFM for the late glacial-Holocene transition (Czymzik et al., 2016). Each dataset is plotted on its original timescale, which is the MFM2012 chronology (Brauer et al., 2000; Martin-Puertas et al., 2012a) and the GICC05 chronology (Rasmussen et al., 2006; Vinther et al., 2006; Svensson et al., 2008; Seierstad et al., 2014). The most striking feature of these datasets is the approximately 250-year-long period of increased ${ }^{10} \mathrm{Be}$ concentration around 11150 years BP. The most likely explanation for this increase is a decrease in the intensity of the heliomagnetic field (solar activity), leading to an increased impingement of Earth by galactic cosmic rays and thus an increased atmospheric production rate of ${ }^{10} \mathrm{Be}$ and ${ }^{14} \mathrm{C}$ nuclides. It was also shown that meteorological and catchment influences on ${ }^{10} \mathrm{Be}$ deposition are likely small at MFM (Czymzik et al., 2016). The high resolution of our ${ }^{10} \mathrm{Be}$ measurements allows us to observe finer structures within this period of increased ${ }^{10} \mathrm{Be}$ concentration. One example is the double peak structure at 11200 and 11040 years $\mathrm{BP}$, which is also present in ${ }^{14} \mathrm{C}$ atmospheric production rate data (Muscheler et al., 2014; Fig. 2) but not expressed well in the GRIP ${ }^{10} \mathrm{Be}$ data. Finally, it is of importance to note that although the increased production around 11150 years BP is observed in all these radionuclide records, there is an apparent chronological offset at its onset around 11300 years BP (Fig. 1). More specifically, the ${ }^{10} \mathrm{Be}$ flux data from GRIP begin to increase around 11320 years BP, whereas a similar increase is seen in the ${ }^{10} \mathrm{Be}$ concentration from MFM around 100 years later, although some short-term features are not visible in all records such as a 40-year-long trough in the MFM ${ }^{10} \mathrm{Be}$ data (ca. $11290-11250$ years BP).

\subsection{Timescale synchronization}

The Greenland ice core timescale is characterized by an accumulating layer counting uncertainty back in time (Rasmussen et al., 2006) as are chronologies based on sediment varve counting such as MFM. In comparison, tree ring chronologies, underlying the ${ }^{14} \mathrm{C}$ calibration record, 

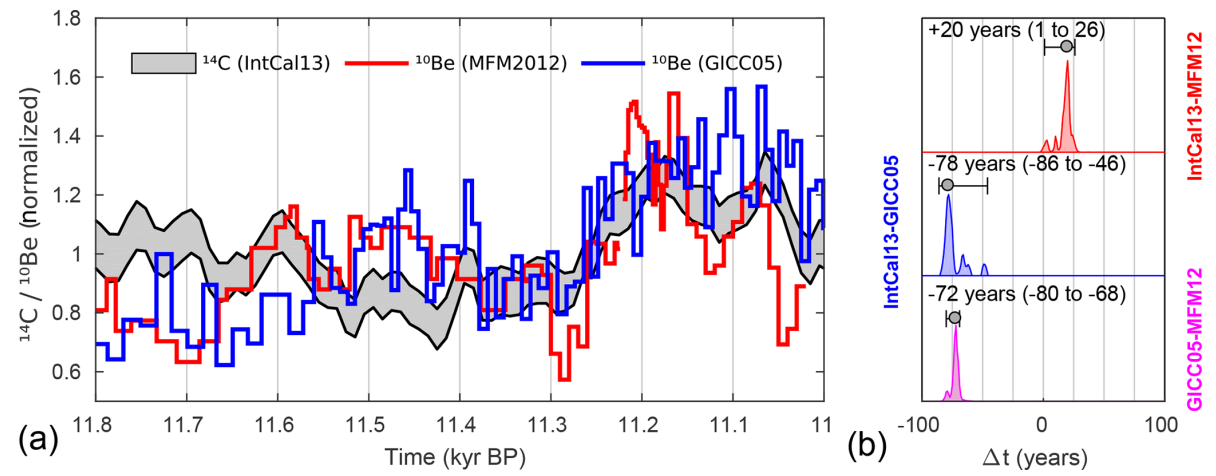

Figure 2. Results from the Bayesian wiggle matching of the different radionuclide records. Panel (a) shows both the MFM ${ }^{10} \mathrm{Be}$ data (in red) and the GRIP ${ }^{10} \mathrm{Be}$ data (blue) once synchronized to the ${ }^{14} \mathrm{C}$ production rate data inferred from the IntCal13 calibration curve (1 $\sigma$ gray envelope). Panel (b) displays the probability density functions for the best fit between IntCal13 and MFM2012 (in red), IntCal13 and GICC05 (in blue), and GICC05 and MFM2012 (in magenta), which resulted in the synchronization in panel (a) with a $95.4 \%$ confidence interval illustrated by the horizontal error bars.

are considered accurate with virtually no dating uncertainty for the Holocene period (Reimer et al., 2013). Considering the different timescale uncertainties, it is challenging to compare the timing of short-lived climate oscillations such as the PBO/11.4 ka event. Here we use the global signature common to all cosmogenic radionuclide records as a synchronization tool (Muscheler et al., 2008, 2014). More specifically, we use the large fluctuations in both the MFM and GRIP ${ }^{10} \mathrm{Be}$ data to synchronize these records with the chronologically more accurate and precise IntCal13 timescale (Czymzik et al., 2018). It was previously shown that GICC05 increasingly overestimates age during the Holocene compared to IntCal13 (Muscheler et al., 2014) and that this timescale difference is estimated to increase to $67( \pm 6)$ years at 11000 years BP (Adolphi and Muscheler, 2016). We use the same Bayesian wiggle matching approach as in Adolphi and Muscheler (2016) but here for the period $11800-11000$ years BP to synchronize both the MFM sediment and Greenland ice core records with IntCal13.

Figure 2 shows both the ice core and sediment core ${ }^{10} \mathrm{Be}$ data once synchronized with the IntCal13 timescale using the ${ }^{14} \mathrm{C}$ production rate from Muscheler et al. (2014), with the corresponding probability density functions displayed in panel (b). We find that the MFM ${ }^{10} \mathrm{Be}$ data fit best with ${ }^{14} \mathrm{C}$ by adding 20 years to MFM2012 $(+6 /-19$ years uncertainty with a $95.4 \%$ confidence interval), whereas the GRIP ${ }^{10} \mathrm{Be}$ data fit best with ${ }^{14} \mathrm{C}$ by shifting GICC05 78 years towards the present $(+32 /-8$ years uncertainty with a $95.4 \%$ likelihood interval). When comparing GICC05 directly to MFM2012, we find that the best fit occurs by shifting GICC05 72 years towards MFM2012 $(+4 /-8$ years with a $95.4 \%$ likelihood interval). There is thus a difference of 26 years $(72+4 /-8$ years versus $98+33 /-21$ years) when comparing GICC05 and MFM2012 directly rather than synchronizing them with IntCal13 first, which illustrates the uncertainties inherent to this exercise. In the following, we will compare GICC05 and MFM2012 when synchronized with IntCal13 as it is the more robust timescale, and then consider the combined chronology offset of $98(+33 /-21)$ years. Another uncertainty from these estimates arises from the influence of climate on the cosmogenic signal of all radionuclides (Adolphi et al., 2014; Muscheler et al., 2008; Pedro et al., 2012). For instance, ${ }^{14} \mathrm{C}$ oxidizes to form ${ }^{14} \mathrm{CO}_{2}$ and enter the carbon cycle, while ${ }^{10} \mathrm{Be}$ readily attaches to aerosols and is thus influenced by precipitation. Even though ${ }^{10} \mathrm{Be}$ deposition is not expected to have strong environmental influences at MFM (Czymzik et al., 2016), this was taken into account within the $20 \%$ uncertainty since these effects are difficult to quantify objectively.

\subsection{Anomalies in paleoclimate proxies between 11450 and 11000 years BP}

If we correct the GICC05 and MFM2012 timescales for their respective offsets to IntCal13, we can compare early Holocene climate in Greenland to data from MFM with a high chronological precision. Figure 3 displays a selection of climatic proxy data from both Greenland ice cores and the varved MFM record on the IntCal13 timescale as per Fig. 2. In addition, both ${ }^{14} \mathrm{C}$ atmospheric production rate and GRIP ${ }^{10} \mathrm{Be}$ flux data are shown as a general indicator of changes in solar activity (Fig. 3a). The stack of $\delta^{18} \mathrm{O}$ anomalies from four Greenland ice cores (DYE-3, GRIP, NGRIP, and Renland; Fig. 3b) can be related to surface air temperature around Greenland (Rasmussen et al., 2007; Vinther et al., 2009) and shows one negative fluctuation between 11400 and 11250 years BP. Following this oscillation, the Greenland $\delta^{18} \mathrm{O}$ anomaly record remains largely constant and positive. In addition, we also use the accumulation rate anomaly stack (Fig. 3c) from the DYE-3, GRIP, and NGRIP ice cores (Rasmussen et al., 2007) to illustrate changes in snow accumulation rates over Greenland. Here again, a negative fluctu- 
ation is observed between 11400 and 11250 years BP. Then, we make use of the MFM $\delta$ D records of $n$-alkanes (Fig. 3d) that have been interpreted as being a proxy for precipitation $\delta \mathrm{D}$ (Rach et al., 2014) which, similar to $\delta^{18} \mathrm{O}$ in Greenland, can thus be regarded as indicative of distance from and temperature and/or humidity at the moisture source (Dansgaard, 1964), as well as fractionation related to air temperature. In contrast to the Greenland stack, the $\delta \mathrm{D}$ data show no fluctuations between 11400 and 11250 years BP with $\delta \mathrm{D}_{\mathrm{aq}}$ remaining constant and $\delta \mathrm{D}_{\text {terr }}$ showing an increasing trend. Then at 11250 years BP, both $\delta \mathrm{D}$ series depict a $20 \%$ drop that persists until 11100 years BP. To test the spatial scale of which the $\delta \mathrm{D}$ record from MFM can be representative, we have investigated the spatial relationship between surface air temperature (SAT) in the NOAA-CIRES 20th climate reanalysis V2c (20CR; Compo et al., 2011) and $\delta \mathrm{D}$ in precipitation at the Trier meteorological station (about $50 \mathrm{~km}$ SW of MFM). It can be seen in Fig. 4 that there is a significant relationship $(p<0.1)$ between annual precipitation $\delta$ D from the Trier station (IAEA/WMO, 2006) and annual SAT over most of western Europe. In addition, Fig. 4 also points to a relationship between annual SATs over Greenland and Iceland and annual $\delta^{18} \mathrm{O}$ at Summit (central Greenland) (Steig et al., 1994; White et al., 2009). Finally, we also show varve thickness changes at MFM that were primarily controlled by runoff from the catchment. After a period of low varve thickness, a sharp increase occurred at 11250 years BP followed by a gradual decrease and a second but very small increase around 11080 years BP. Titanium-centered $\log$ ratio data $\left(\mathrm{Ti}_{\mathrm{clr}}\right)$, determined by micro $\mathrm{X}$-ray fluorescence ( $\mu$-XRF) from the same MFM sediment composite profile (Martin-Puertas et al., 2017), confirm the interpretation that the variance in varve thickness at the time was mostly controlled by detrital supply to the lake (Fig. 3e). It is important to mention that in a longer time perspective, the changes described above in the sediments of MFM (Martin-Puertas et al., 2017; Rach et al., 2014) do not exceed other fluctuations in varve thickness and $\mathrm{Ti}_{\mathrm{clr}}$.

\section{Discussion}

\subsection{Timing and interpretation of anomalies between 11450 and 11000 years BP}

In Greenland, a cold and dry climate episode occurred around 11400-11250 years BP known as the 11.4 ka event (Rasmussen et al., 2007). This is evidenced by a significant drop in the signal of the Greenland ice core $\delta^{18} \mathrm{O}$ stack, as well as in the accumulation stack (Fig. 3b, c). By shifting GICC05 78 years towards the present, the central part of the $11.4 \mathrm{ka}$ event (lowest value in $\delta^{18} \mathrm{O}$ ) is dated to around 11372 $11272(+32 /-8)$ years BP, which is consistent with GICC05 within the combined uncertainty of our synchronization and the maximum counting error in GICC05. When looking at the temperature proxy and varve thickness data from MFM
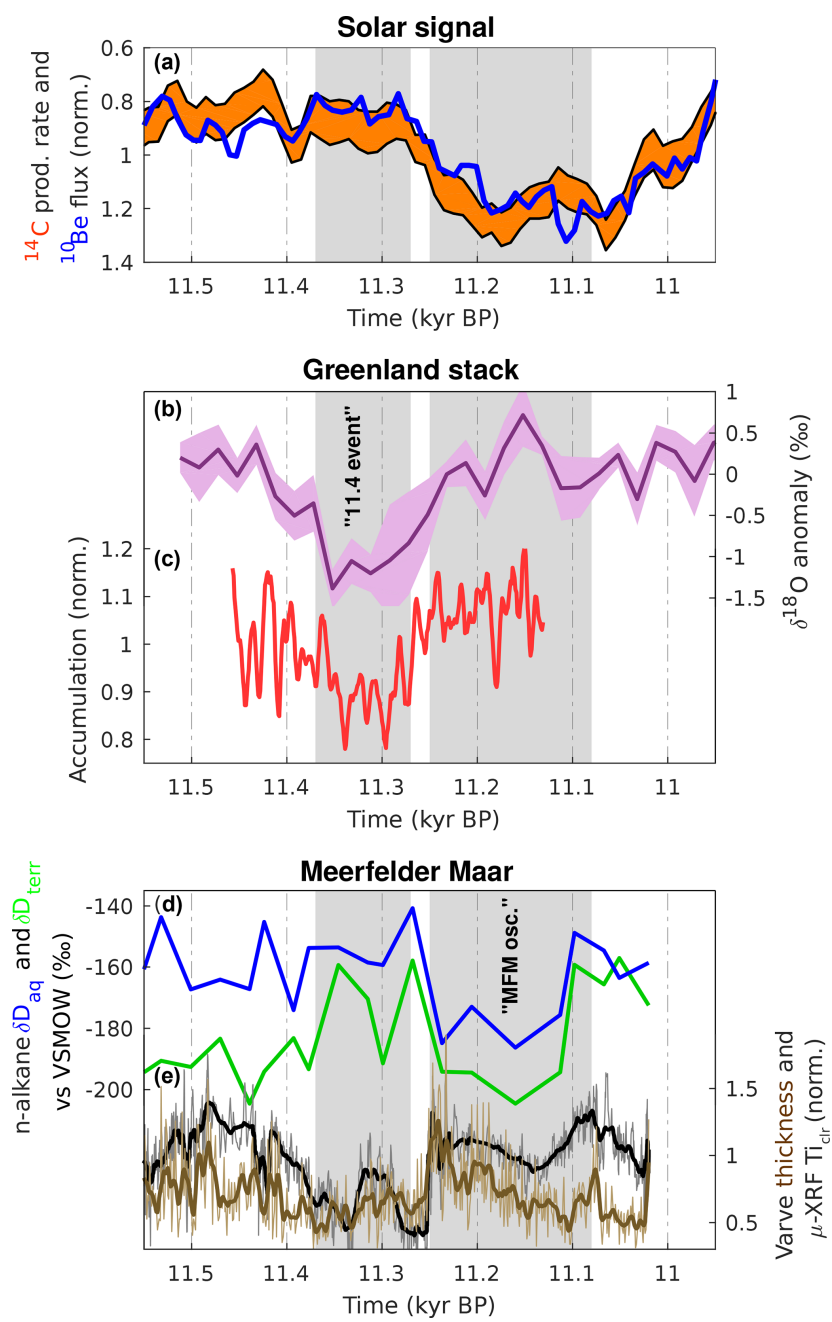

Figure 3. (a) ${ }^{14} \mathrm{C}$ production rate (orange envelope) and GRIP ${ }^{10} \mathrm{Be}$ data (blue) on a reversed $y$ axis to indicate variations in solar activity. (b) The $\delta^{18} \mathrm{O}$ stack from the DYE-3, GRIP, NGRIP, and Renland ice cores (Rasmussen et al., 2007; Vinther et al., 2009) is shown in magenta, and (c) the modeled accumulation anomalies from Rasmussen et al. (2007) for DYE-3, GRIP, and NGRIP are shown in red. (d) The $\delta \mathrm{D}$ data record from lipid biomarkers of MFM sediments (Rach et al., 2014) is plotted in blue and green (aquatic and terrestrial), while (e) varve thickness (Martin-Puertas et al., 2012a) and varve $\mu$-XRF Ticlr (Martin-Puertas et al., 2017) are plotted in brown and black, respectively. The gray bands depict the time of occurrence of the $11.4 \mathrm{ka}$ event in Greenland and of the cold oscillation inferred from the MFM sediments (MFM oscillation). All data are plotted on the IntCal13 timescale as per Fig. 2.

(Fig. 3d, e), we do not find any event that is coeval with the $11.4 \mathrm{ka}$ event in Greenland. Interestingly though, $\mathrm{Ti}_{\mathrm{clr}}$ data (Fig. 3e) gradually decreased from ca. 11490 years BP only to be interrupted by a small increase around 11300 years BP. The low $\mathrm{Ti}_{\text {clr }}$ data suggest less runoff probably related to drier conditions, which shows some commonality with the conditions in Greenland at that time (11.4 oscillation) evi- 
denced by the lower accumulation rate. Therefore, a possible link to the dry Rammelbeek Phase described in the Borchert peat sequence in the Netherlands (van der Plicht et al., 2004; Bos et al., 2007) may be tentatively put forward, although chronological uncertainties hinder proving this. We can now also confidently deduce that the termination of the $\delta^{18} \mathrm{O}$ and accumulation anomalies in Greenland (the $11.4 \mathrm{ka}$ event) is synchronous with a large decrease in solar activity (Fig. 3a-c). More specifically, high levels of solar activity prevailed throughout the occurrence of the $11.4 \mathrm{ka}$ event in Greenland. Then, as solar activity started to decrease (ca. 11250 years BP) into a grand solar minimum that lasted for around 250 years, the climate in Greenland switched back to warmer and wetter conditions with higher $\delta^{18} \mathrm{O}$ values and a higher accumulation rate. This is in accordance with the suggestion of an abrupt warming $\left(4^{\circ} \pm 1.5^{\circ}\right)$ in Greenland following the event based on $\delta^{15} \mathrm{~N}$ in the GIPS2 ice core (Kobashi et al., 2008). The rapid transition towards positive accumulation anomalies occurred over a few decades only.

While climate over Greenland following the 11.4 ka event returned rapidly to warmer and wetter conditions, all proxies from MFM sediments (Fig. 3d, e) show fluctuations around 11250 years BP (henceforth MFM oscillation). In particular, aquatic $\delta \mathrm{D}$ data from small-chain alkanes (Rach et al., 2014) show a clear oscillation with a $20 \%$ drop around 11250 years BP (Fig. 3d), while terrestrial $\delta \mathrm{D}$ data show a decrease reaching levels seen around 11500 years BP. This deuterium depletion in the alkanes most likely mirrors a depletion of deuterium in precipitation which can be explained, in part, by lower air temperatures over western Europe in view of Fig. 4. Simultaneously, varve thickness and $\mathrm{Ti}_{\mathrm{clr}}$ show a rapid increase at 11250 years BP (Fig. 3e), denoting a likely increasing detrital contribution to this varve thickening. When considered in a longer time perspective (Martin-Puertas et al., 2017), this varve increase reaches the level of other fluctuations that are unrelated to known early Holocene oscillations in North Atlantic climate. Nevertheless, this shift at 11250 year BP does correspond to a change in the composition of the sediments as Martin-Puertas et al. (2017) defined a compositional boundary of MFM varves at 11230 years BP (11 250 years BP on the IntCal13 timescale) based on $\mu$-XRF scanning analyzed with Ward's clustering methods. By synchronizing MFM2012 with IntCal13 (Fig. 2), we find that this compositional boundary is also coeval with the onset of the grand solar minimum (Fig. 3), although the cause of this change is difficult to assess. In fact, $\mathrm{Ti}_{\mathrm{clr}}$, as well as $\ln (\mathrm{Si} / \mathrm{Ti})$ and $\ln (\mathrm{Ca} / \mathrm{Ti})$, which is generally regarded by Martin-Puertas et al. (2017) as indicating relative changes in biogenic silica concentrations and authigenic calcite precipitation, is significantly correlated with the new ${ }^{10} \mathrm{Be}$ concentration measurements and also with the GRIP ${ }^{10} \mathrm{Be}$ data and with the ${ }^{14} \mathrm{C}$ atmospheric production rate (Figs. 5 and $\mathrm{S} 1$ in the Supplement). Because GRIP ${ }^{10} \mathrm{Be}$ data and the ${ }^{14} \mathrm{C}$ atmospheric production rate are unaffected by environmental changes at MFM, we suggest that the catchment area of

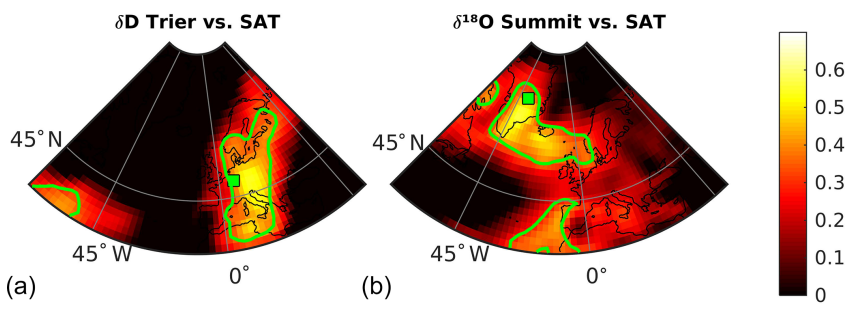

Figure 4. (a) Correlation map between annual $\delta \mathrm{D}$ in precipitation from the Trier station (green square; IAEA/WMO, 2016) and annual surface air temperatures in the NOAA-CIRES 20th climate reanalysis V2c (Compo et al., 2011) for the period 1978-2011 CE. (b) Same as (a) but for $\delta^{18} \mathrm{O}$ from the GISP2 ice core (green square; Steig et al., 1994; White et al., 2009) and for the period 1950-1986 CE. Green contour lines represent significance levels for $p<0.1$ ( $t$ test). The difference in years selected arises from the different time span of the $\delta \mathrm{D}$ and $\delta^{18} \mathrm{O}$ records used here.

MFM was likely influenced by the substantial changes in solar activity that characterized this period rather than ${ }^{10} \mathrm{Be}$ concentration at MFM being affected by this sediment compositional change. In support of this assumption, Czymzik et al. (2016) also reported negligible climate influences on

${ }^{10} \mathrm{Be}$ deposition at MFM even across distinct climatological boundaries. It can also be seen that the second and smaller increase in varve thickness and $\mathrm{Ti}_{\mathrm{clr}}$ is coeval with a second dip in solar activity shortly after 11100 years BP (Fig. 3a and e). Finally, it is worthwhile to note that the percentage values of Pinus pollen and biogenic silica, as well as pollen concentrations in MFM, all decreased at 11 250-11230 years BP while percentage values of Betula increased (Brauer et al., 1999). Although not interpreted by the authors, these changes echo the findings of Björck et al. (1997), who defined the PBO in terrestrial records of Sweden with a similar decrease in pollen concentrations and more notably of Pinus pollen percentages, interpreted as a setback of tree vegetation in southern Sweden. It should be stressed here that we cannot directly compare the palynology of MFM to these Swedish lakes because of the challenging interpretation of the former record, as well as the chronological uncertainties and the vicinity to the retreating Fennoscandian Ice Sheet (FIS) of the later records.

In summary, the radionuclide-based synchronization of the GICC05 and MFM2012 timescales indicates a combined timing offset of up to $98(+33 /-21)$ years during the earliest part of the Holocene. Correcting for this offset, we observe that cold oscillations at both locations and inferred from water isotopes did not occur simultaneously between 11450 and 11000 years BP. We further note that this pattern appears to be coupled with large changes in solar activity, which leads us to suggest a causal link. More specifically, the cold and dry climate oscillation in Greenland (the 11.4 ka event) occurred under a period of high solar activity between ca. 11370 and 11270 years BP but did not leave a discernable imprint in 


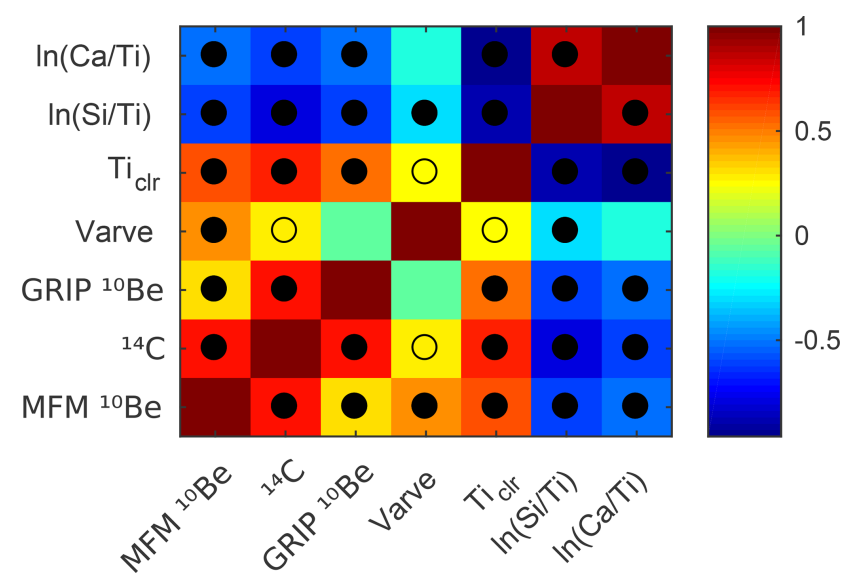

Figure 5. Color-coded correlation matrix between MFM ${ }^{10} \mathrm{Be}$ concentration, GRIP ${ }^{10} \mathrm{Be}$ flux, ${ }^{14} \mathrm{C}$ production rate data, varve thickness, and $\mu$-XRF data from MFM09 (Martin-Puertas et al., 2017). Open and filled circles denote significant correlations with the $p<$ 0.1 and the $p<0.05$ levels, respectively. All data were binned after the resolution of the MFM ${ }^{10} \mathrm{Be}$ concentration data for the period 11310-11000 years BP, and the Student $t$ test was performed to test the significance levels.

either varve thickness or biomarker $\delta \mathrm{D}$ from MFM. Subsequently, solar activity dropped to a grand minimum that lasted for as long as 250 years. This change was coeval with the termination of the $11.4 \mathrm{ka}$ event (Greenland) and the onset of the MFM oscillation with colder conditions inferred from $\delta \mathrm{D}$ data (Figs. $3 \mathrm{~d}$ and 4 ). The ostensible link with solar activity which we infer in view of Fig. 3 resembles what has been described substantially in the recent literature and is discussed in the following section.

\subsection{Solar forcing during $11450-11000$ years BP}

Our suggestion of a causal sun-climate link during the earliest part of the Holocene can be further supported by the spatial patterns of the $11.4 \mathrm{ka}$ event in Greenland followed by a cold period at MFM starting at 11250 years BP (MFM oscillation). Based on our synchronization of the different paleoclimate records, we find an asynchronous relationship between the Greenland and European climates, characterized by cold and dry conditions over Greenland but with no evidence of it at MFM under high solar activity and a warm and wetter Greenland climate, as well as colder conditions at MFM for low solar activity (Fig. 3).

This pattern is consistent with a number of, but not all, climate modeling studies that find a top-down influence of solar activity on North Atlantic and European atmospheric circulation patterns. This forcing mechanism involves the increase in UV radiation during solar maximum years (Haigh et al., 2010; Lockwood et al., 2010), which enhances the production of stratospheric ozone and leads to stratospheric heating through the increased absorption of longwave radia- tion (Haigh et al., 2010), especially at the Equator. This increases the stratospheric temperature gradient between the Equator and poles (Simpson et al., 2009), leading to an acceleration of the polar night jet (Kodera et al., 2002), which eventually propagates down to the troposphere via wave refraction (Matthes et al., 2006; Ineson et al., 2011). In turn, this leads to patterns in surface pressure and temperature which mimic those of the positive phase of the North Atlantic Oscillation (NAO) in winter (Woollings et al., 2010; Ineson et al., 2011). The opposite mode applies during periods of solar minima. It should, however, be stressed that there is no consistent correlation between the North Atlantic Oscillation and solar forcing for the past centuries (Gray et al., 2013; Ortega et al., 2015), although a solar influence on the region is not necessarily related to the NAO (Moffa-Sánchez et al., 2014; Sjolte et al., 2018). Even though the spatial pattern we observe agrees well with a top-down solar forcing, other mechanisms cannot be excluded as lying behind the different North Atlantic response patterns. Overall, it has to be kept in mind that different time periods with different climate boundary conditions could lead to shifting atmospheric patterns.

In the following we explore the solar hypothesis further by investigating a modern analog with climate reanalysis data. Figure 6a shows the surface air temperature (SAT) anomalies in the North Atlantic region for periods of solar maxima compared to periods of solar minima in 20CR (mean $\pm 1 \sigma$ of the sunspot group numbers from Svalgaard and Schatten, 2016, between 1946 and 2011 CE; see Fig. S2). It can be seen from the SAT anomalies that a distinct antiphase pattern between Greenland and Europe is coincident with highs and lows in solar activity. That is to say that Greenland experiences lower SATs during winters of solar maxima compared to winters of solar minima, whereas lower SATs are observed across Europe for winters of solar minima compared to winters of solar maxima. This highlights the correspondence between the solar influence on North Atlantic climate, which has been proposed to have been active during the 20th century, and the synchronized climate proxy records during the early Holocene in terms of spatial distribution of SAT anomalies. Furthermore, this correspondence can also be qualitatively described by comparing the mean annual temperature anomalies at both Summit (central Greenland) and MFM (Fig. 6c, d) through an average of all 11-year solar cycles of the 20th century (Fig. 6b). Decadal temperature changes in 20CR at both Summit (blue curve in Fig. 6c) and MFM (red curve in Fig. 6d) agree qualitatively well with centennial $\delta^{18} \mathrm{O}$ and $\delta \mathrm{D}$ changes observed in Greenland ice cores and in MFM sediments during the period ranging from 11450 to 11000 years BP (black curves in Fig. 6c, d; note the different time axes). Of specific interest here is the average transition from high to low solar activity that is coincident with an annual temperature rise or drop of ca. $1 \mathrm{~K}$ at Summit and/or MFM. Assuming changes in water isotopes to be, in part, indicative of regional temperature changes (Dans- 
gaard, 1964; Masson-Delmotte et al., 2005; Rach et al., 2014; Fig. 4), this decadal pattern between Summit and MFM in climate reanalysis data mimics the centennial-scale climate changes that prevailed in Greenland and Europe throughout the period 11450-11 000 years BP. Water isotopes are often dominated by a particular seasonal signal. It is therefore of interest to note that the spatial patterns observed in climate reanalysis are also present during the summer, although to a lesser degree (Fig. 3).

It should be noted that the efficiency of the topdown mechanism remains largely unexplored for centennial timescales. For instance, previous studies have proposed a top-down solar influence on atmospheric circulation on similar timescales for both Greenland (Adolphi et al., 2014) and MFM (Martin-Puertas et al., 2012b), leading to a similar spatial pattern in reanalysis data. The modeling results in these studies, however, only investigate the effect of decadal (11year) changes in solar activity. In contrast, it was also shown more recently that the centennial response of North Atlantic atmospheric circulation to solar forcing is correlated with the second mode of atmospheric circulation, the East Atlantic pattern, rather than to the first mode, the NAO (Sjolte et al., 2018). The latter study consequently does not find a similar pattern in SAT anomalies between Greenland and western Europe.

For the same reasons, another uncertainty arises from the relevance of using 20th century climate reanalysis as an analogy of early Holocene conditions. In particular, the Laurentide Ice Sheet (LIS) is known to have played an important role in the position of the North Atlantic eddy-driven jet by accelerating and displacing it southward (Merz et al., 2015). However, it is also known that the LIS waned to the point of separation with the Cordilleran at around 14000 years BP (Dyke, 2004). According to a study based on a transient climate simulation from the Last Glacial Maximum (LGM) (Löfverström and Lora, 2017), this separation led to a shift in the dominant topographic stationary wave source in North America. This, in turn, induced a transition from a strong and subtropical jet stream to a weaker and more meridionally tilted jet stream and storm track as observed for present conditions. This suggests that similar atmospheric processes could have been at play during the earliest part of the Holocene, relative to today, in spite of different boundary conditions. Furthermore, the results in Fig. 6 arise from an 11-year solar cycle forcing which is considerably weaker and less persistent than the potential solar forcing that the 11400 years BP solar maximum to 11200 years BP grand solar minimum could have provoked, leading to possibly different reactions due to feedback processes. In fact, both the ${ }^{14} \mathrm{C}$ data and GRIP ${ }^{10} \mathrm{Be}$ data shown in Fig. 2 depict one of the most prominent increases in the Holocene record (Vonmoos et al., 2006) in terms of both amplitude and the duration of the grand solar minimum. In comparison, its duration represents twice the length of the longest grand minimum known from sunspot observations (Svalgaard and Schatten, 2016) and is called the Maunder Minimum (1645-1715 CE).

\subsection{Solar-ocean coupling}

The PBO has also been associated with an increase in freshwater supply hampering the Atlantic meridional overturning circulation (AMOC) possibly from the Baltic Ice Lake drainage and the rapidly waning Fennoscandian Ice Sheet (Björck et al., 1996; Hald and Hagen, 1998). It was next proposed by Fisher et al. (2002) that an outburst of Lake Agassiz could represent the trigger of the PBO through an increased thickness and extent of Arctic Ocean sea-ice pack. This would have resulted in an increased albedo and a slowdown of North Atlantic Deep Water (NADW) formation due to increased freshwater delivery to the North Atlantic. However, the timing of the outburst event to which they attribute the PBO (11335 years cal BP) has rather large uncertainties ( \pm 130 to 230 years) due to the $\Delta^{14} \mathrm{C}$ age plateau in this period. More recently, it was suggested that even small changes in the prevalence of the AMOC can influence atmospheric circulation with couplings to the NAO, with an intensification of the former resulting in a negative index of the latter (Frankignoul et al., 2013).

To further investigate the potential spatial distribution of SAT anomalies due to a slowdown of the AMOC, we again investigate $20 \mathrm{CR}$ for winters with a negative reconstructed AMOC index (Duchez et al., 2014) compared to winters with a positive reconstructed AMOC index for the period 19612005 CE (Fig. 7a). Interestingly, SAT anomalies similar to those for solar forcing subside. That is to say that an amplified meridional temperature gradient with a colder Greenland and a warmer western Europe is favored in winters in which the AMOC is weaker relative to winters in which it is stronger. Although it is difficult to obtain direct evidence of an AMOC slowdown during the early Holocene, it is conceivable that the waning Fennoscandian Ice Sheet would have routinely released enough freshwater to weaken and condition the AMOC for the onset of the $11.4 \mathrm{ka}$ event in Greenland. This result could also be explained by the influence of the NAO on the AMOC index as it is difficult to disentangle these tightly coupled processes (McCarthy et al., 2015). In this case, the persistent high levels of solar activity, which can also favor such temperature and pressure patterns, could represent a potential trigger for these climate oscillations. Figure $7 \mathrm{~b}$ depicts the large temperature differences for winters in which both high solar activity and a weak AMOC prevailed during the period 1961-2005 CE with up to $\mathrm{a}-4 \mathrm{~K}$ anomaly in western Greenland. This, however, needs to be treated with caution due to the relatively short period of observation that results in having very few years when such solar activity and AMOC conditions existed in parallel (Fig. 4).

In addition, a coupling between solar and freshwater forcing could also explain the lack of significant climate re- 

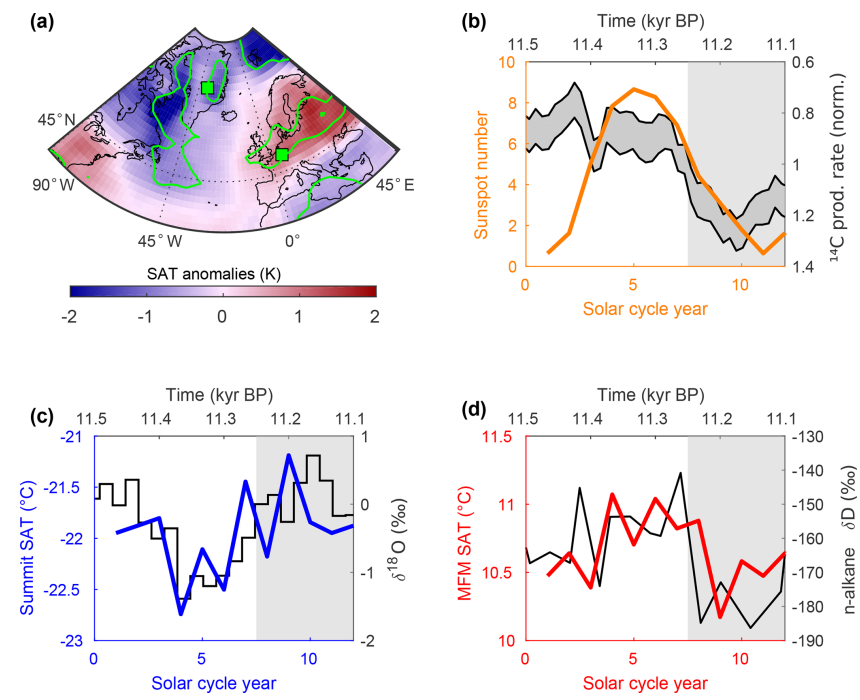

Figure 6. The $11.4 \mathrm{ka}$ event and MFM oscillation compared to the solar forcing of 20th century SATs in the North Atlantic region as seen in 20CR. (a) Surface air temperature (SAT) anomalies for solar maximum winters (DJF) compared to solar minimum winters (see Fig. S2) for the period 1946-2011 CE in 20th century climate reanalysis (Compo et al., 2011). The green squares point to the location of Summit and of MFM, while the green contour lines represent significance levels for $p<0.1$ ( $t$ test). Years influenced by large tropical volcanic eruptions have been removed as per Ineson et al. (2011). (b) The transition between high to low solar activity in the ${ }^{14} \mathrm{C}$ production rate data (gray envelope, top and right axes) compared to the mean sunspot group number of all 11-year solar cycles between 1900 and $2011 \mathrm{CE}$ (orange curve, bottom and left axes). (c) The $\delta^{18} \mathrm{O}$ stack (black curve, top and right axes) shown in Fig. 3b compared to the mean SAT at Summit (blue curve, bottom and left axes) throughout all 11-year solar cycles between 1900 and $2011 \mathrm{CE}$ as in (b). (d) Same as (c) but with $\delta \mathrm{D}$ (black curve, top and right axes) and MFM SAT (red curve, bottom and left axes). Note the different timescale on the top (paleoclimate records) and bottom (reanalysis data) axes. The gray bands show the periods of low solar activity occurring in the two time periods that are compared.
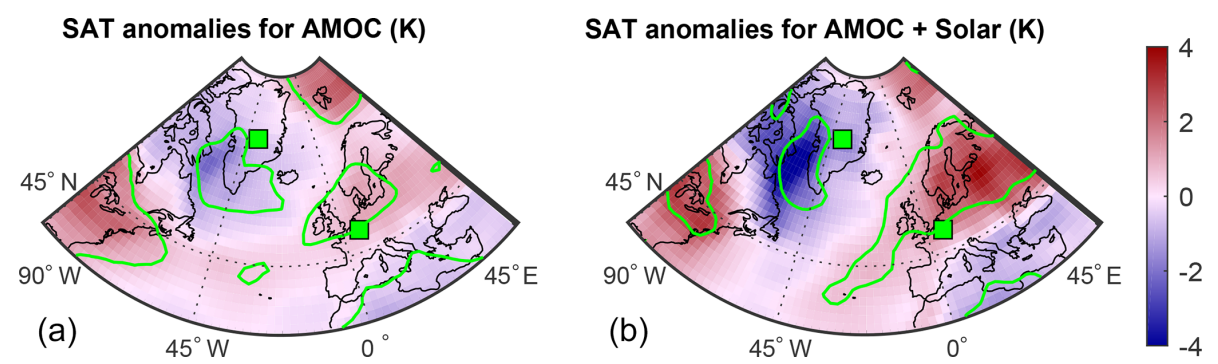

Figure 7. (a) Winter (DJF) surface air temperature anomalies for negative AMOC years compared to positive AMOC years for the period 1961-2005 CE in 20th century climate reanalysis (see Fig. S4). The green markers point to the location of Summit and of MFM, while the green contour lines represent significance levels for $p<0.1$ ( $t$ test). (b) Same as (a) but for years of both negative AMOC and high solar activity.

sponses to subsequent grand solar minima which were also large in amplitude but did not yield an unequivocal impact on North Atlantic climate. It is indeed notable that the following changes in solar activity occurred while the influence of freshwater release by the FIS was diminishing, and therefore the North Atlantic was not conditioned as it was during the PBO. For instance, a similar but weaker event was found in the $\delta^{18} \mathrm{O}$ signal of the GRIP ice core around 10300 years cal $\mathrm{BP}$, coinciding with a low in $\Delta^{14} \mathrm{C}$ (high solar activity) and a cooling in the Faroe Islands (Björck et al., 2001). In contrast, the subsequent grand solar minimum which occurred around 9500 years BP (Vonmoos et al., 2006), at a time during which the FIS had completely vanished (Stroeven et al., 2016), did not coincide with any evident climate oscillation in Greenland.

\section{Conclusions}

A comparison of new ${ }^{10} \mathrm{Be}$ concentration measurements from the varved Meerfelder Maar sediments covering the period $11310-11000$ years $\mathrm{BP}$ to the ${ }^{10} \mathrm{Be}$ data from the GRIP ice core in central Greenland showed a combined offset of up to $98(+33 /-21)$ years between the MFM2012 and GICC05 chronologies. Correcting for this offset allowed us to deter- 
mine that the 11.4 ka event in Greenland has no coeval counterparts in Meerfelder Maar and that it coincides with high solar activity. The timescale synchronization also showed that an environmental shift at MFM starting at 11250 years $\mathrm{BP}$ is coincident with a transition from high solar activity to a particularly long-lasting grand solar minimum, as well as with the termination of the $11.4 \mathrm{ka}$ event in Greenland. The termination and onset of these cold oscillations in Greenland and then Meerfelder Maar are thus synchronous with large changes in solar activity, which is a pattern reproduced by a number of modeling studies. Finally, we also postulate that a slowdown of the AMOC due to freshwater delivery from, for instance, the Fennoscandian Ice Sheet could have served as a potential amplifier to this signal. The extent of the role that solar activity changes may have played in the climate of Greenland and Europe during the earliest part of the Holocene is unclear. This is due to the different boundary conditions which prevailed at the time compared to today but also due to the proxy evidence from MFM which is difficult to interpret. The main results from this study do, however, exemplify the usefulness of cosmogenic radionuclides in synchronizing different paleoclimate records when investigating the timing and spatial distribution of past climate fluctuations with a high chronological precision.

Data availability. The new ${ }^{10} \mathrm{Be}$ data from this study are available on the PANGAEA open-access data library (https://doi.org/10.1594/PANGAEA.907808, Mekhaldi, 2019).

Supplement. The supplement related to this article is available online at: https://doi.org/10.5194/cp-16-1145-2020-supplement.

Author contributions. FM performed the analysis in correspondence with RM, carried out the sampling with MC and CMP, and did the chemical preparation of the Meerfelder Maar ${ }^{10} \mathrm{Be}$ samples with the help of AA, while GP performed the measurements. FM wrote the paper. RM, MC, and FM initiated the project. FA provided the Bayesian synchronization and participated in the interpretation of the climate reanalysis with JS. SB, AB, MC, and CMP assisted with the interpretation of the proxy data. All authors were involved in editing the paper.

Competing interests. The authors declare that they have no conflict of interest.

Acknowledgements. The authors would like to thank Inger Påhlsson for her help with the chemical preparation of the sediment ${ }^{10} \mathrm{Be}$ samples for AMS measurements.
Financial support. This research has been supported by the Royal Physiographic Society of Lund (application no. 36278 to Florian Mekhaldi) and the Swedish Research Council (grant no. DNR2013-8421 to Raimund Muscheler). Markus Czymzik was funded by a grant from the German Research Foundation (DFG) (grant no. CZ 227/4-1) and the BaltRap network of the Leibniz Association (SAW-2017-IOW2). Florian Adolphi was supported by the Swedish Research Council (grant no. DNR2016-00218). Ala Aldahan thanks the UAEU for the support through the UPAR funding.

Review statement. This paper was edited by Hans Linderholm and reviewed by three anonymous referees.

\section{References}

Adolphi, F. and Muscheler, R.: Synchronizing the Greenland ice core and radiocarbon timescales over the Holocene - Bayesian wiggle-matching of cosmogenic radionuclide records, Clim. Past, 12, 15-30, https://doi.org/10.5194/cp-12-15-2016, 2016.

Adolphi, F., Muscheler, R., Svensson, A., Aldahan, A., Possnert, G., Beer, J., Sjolte, J., Björck, S., Matthes, K., and Thiéblemont, R.: Persistent link between solar activity and Greenland climate during the Last Glacial Maximum, Nat. Geosci., 7, 662-666, https://doi.org/10.1038/ngeo2225, 2014.

Berggren, A.-M., Aldahan, A., Possnert, G., Haltia-Hovi, E., and Saarinen, T.: ${ }^{10} \mathrm{Be}$ and solar activity cycles in varved lake sediments, AD 1900-2006, J. Paleolimnol., 44, 559-569, https://doi.org/10.1007/s10933-010-9437-1, 2010.

Bos, J. A. A., van Geel, B., van der Plicht, J., and Bohncke, S. J. P.: Preboreal climate oscillations in Europe: Wiggle-match dating and synthesis of Dutch high-resolution multi-proxy records, Quaternary Sci. Rev., 26, 1927-1950, https://doi.org/10.1016/j.quascirev.2006.09.012, 2007.

Björck, S., Kromer, B., Johnsen, S., Bennike, O., Hammarlund, D., Lemdahl, G., Possnert, G., Rasmussen, T. L., Wohlfarth, B., Hammer, C. U., and Spurk, M.: Synchronized Terrestrial-Atmospheric Deglacial Records Around the North Atlantic, Science, 274, 1155-1160, https://doi.org/10.1126/science.274.5290.1155, 1996.

Björck, S., Rundgren, M., Ingólfsson, Ó., and Funder, S.: The Preboreal oscillation around the Nordic Seas: terrestrial and lacustrine responses, J. Quaternary Sci., $\quad 12, \quad 455-465, \quad$ https://doi.org/10.1002/(SICI)10991417(199711/12)12:6<455::AID-JQS316>3.0.CO;2-S, 1997.

Björck, S., Muscheler, R., Kromer, B., Andresen, C. S., Heinemeier, J., Johnsen, S. J., Conley, D., Koç, N., Spurk, M., and Veski, S.: High-resolution analyses of an early Holocene climate event may imply decreased solar forcing as an important climate trigger, Geology, 29, 1107, https://doi.org/10.1130/00917613(2001)029<1107:HRAOAE > 2.0.CO;2, 2001.

Brauer, A., Endres, C., Günter, C., Litt, T., Stebich, M., and Negendank, J. F. W.: High resolution sediment and vegetation responses to Younger Dryas climate change in varved lake sediments from Meerfelder Maar, Germany, Quaternary Sci. Rev., 18, 321-329, https://doi.org/10.1016/S0277-3791(98)00084-5, 1999. 
Brauer, A., Endres, C., Zolitschka, B., and Negendank, J. F.: AMS radiocarbon and varve chronology from the annually laminated sediment record of Lake Meerfelder Maar, Germany, Radiocarbon, 42, 355-368, 2000.

Bronk Ramsey, C., van der Plicht, J., and Weninger, B.: "Wiggle matching" radiocarbon dates, Radiocarbon, 43, 381-390, 2001.

Compo, G. P., Whitaker, J. S., Sardeshmukh, P. D., Matsui, N., Allan, R. J., Yin, X., Gleason, B. E., Vose, R. S., Rutledge, G., Bessemoulin, P., Brönnimann, S., Brunet, M., Crouthamel, R. I., Grant, A. N., Groisman, P. Y., Jones, P. D., Kruk, M. C., Kruger, A. C., Marshall, G. J., Maugeri, M., Mok, H. Y., Nordli, Ø., Ross, T. F., Trigo, R. M., Wang, X. L., Woodruff, S. D., and Worley, S. J.: The Twentieth Century Reanalysis Project, Q. J. Roy. Meteor. Soc., 137, 1-28, https://doi.org/10.1002/qj.776, 2011.

Czymzik, M., Adolphi, F., Muscheler, R., Mekhaldi, F., MartinPuertas, C., Aldahan, A., Oran Possnert, G. €and Brauer, A.: A varved lake sediment record of the ${ }^{10} \mathrm{Be}$ solar activity proxy for the Lateglacial-Holocene transition, Quaternary Sci. Rev., 153, 31-39, https://doi.org/10.1016/j.quascirev.2016.10.007, 2016.

Czymzik, M., Muscheler, R., Adolphi, F., Mekhaldi, F., Dräger, N., Ott, F., Słowinski, M., Błaszkiewicz, M., Aldahan, A., Possnert, G., and Brauer, A.: Synchronizing ${ }^{10} \mathrm{Be}$ in two varved lake sediment records to IntCal13 ${ }^{14} \mathrm{C}$ during three grand solar minima, Clim. Past, 14, 687-696, https://doi.org/10.5194/cp-14-6872018, 2018.

Dansgaard, W.: Stable isotopes in precipitation, Tellus, 16, 436468, https://doi.org/10.3402/tellusa.v16i4.8993, 1964.

Duchez, A., Hirschi, J. J.-M, Cunningham, S. A., Blaker, A. T., Bryden, H. L., De Cuevas, B., Atkinson, C. P., Mccarthy, G. D., Frajka-Williams, E., Rayner, D., Smeed, D., and Mizielinski, M. S.: A new index for the Atlantic Meridional Overturning Circulation at $26^{\circ} \mathrm{N}$, J. Climate, 27, 6439-6455, https://doi.org/10.1175/JCLI-D-13-00052.1, 2014.

Dyke, A. S.: An outline of North American deglaciation with emphasis on central and northern Canada, Developments in Quaternary Sciences, 2, 373-424, https://doi.org/10.1016/S15710866(04)80209-4, 2004.

Finkel, R. C. and Nishiizumi, K.: Beryllium 10 concentrations in the Greenland Ice Sheet Project 2 ice core from 3-40 ka, J. Geophys. Res., 102, 26699-26706, https://doi.org/10.1029/97JC01282, 1997.

Fisher, T. G., Smith, D. G., and Andrews, J. T.: Preboreal oscillation caused by a glacial Lake Agassiz flood, Quaternary Sci. Rev., 21, 873-878, https://doi.org/10.1016/S0277-3791(01)00148-2, 2002.

Frankignoul, C., Gastineau, G., and Kwon, Y. O.: The influence of the AMOC variability on the atmosphere in CCSM3, J. Climate, 26, 9774-9790, https://doi.org/10.1175/JCLI-D-12$00862.1,2013$.

Gray, L. J., Scaife, A. A., Mitchell, D. M., Osprey, S., Ineson, S., Hardiman, S., Butchart, N., Knight, J., Sutton, R., and Kodera, K.: A lagged response to the 11 year solar cycle in observed winter Atlantic/European weather patterns, J. Geophys. Res.-Atmos., 118, 13405-13420, https://doi.org/10.1002/2013JD020062, 2013.

Haigh, J. D., Winning, A. R., Toumi, R., and Harder, J. W.: An influence of solar spectral variations on radiative forcing of climate, Nature, 467, 696-699, https://doi.org/10.1038/nature09426, 2010 .
Hald, M. and Hagen, S.: Early Preboreal cooling in the Nordic seas region triggered by meltwater, Geology, 26, 615-618, https://doi.org/10.1130/00917613(1998)026<0615:EPCITN>2.3.CO;2, 1998.

Ineson, S., Scaife, A. A., Knight, J. R., Manners, J. C., Dunstone, N. J., Gray, L. J., and Haigh, J. D.: Solar forcing of winter climate variability in the Northern Hemisphere, Nat. Geosci., 4, 753-757, https://doi.org/10.1038/ngeo1282, 2011.

Kobashi, T., Severinghaus, J. P., and Barnola, J.-M.: $4 \pm 1.5^{\circ} \mathrm{C}$ abrupt warming $11,270 \mathrm{yr}$ ago identified from trapped air in Greenland ice, Earth Planet. Sc. Lett., 268, 397-407, https://doi.org/10.1016/j.epsl.2008.01.032, 2008.

Kodera, K.: Solar cycle modulation of the North Atlantic Oscillation: Implication in the spatial structure of the NAO, Geophys. Res. Lett., 29, 59-1-59-4, https://doi.org/10.1029/2001GL014557, 2002.

Lane, C. S., Brauer, A., Martín-Puertas, C., Blockley, S. P. E., Smith, V. C., and Tomlinson, E. L.: The Late Quaternary tephrostratigraphy of annually laminated sediments from Meerfelder Maar, Germany, Quaternary Sci. Rev., 122, 192-206, https://doi.org/10.1016/j.quascirev.2015.05.025, 2015.

Lockwood, M., Bell, C., Woollings, T., Harrison, R. G., Gray, L. J., and Haigh, J. D.: Top-down solar modulation of climate: evidence for centennial-scale change, Environ. Res. Lett., 5, 34008, https://doi.org/10.1088/1748-9326/5/3/034008, 2010.

Löfverström, M. and Lora, J. M.: Abrupt regime shifts in the North Atlantic atmospheric circulation over the last deglaciation, Geophys. Res. Lett., 44, 8047-8055, https://doi.org/10.1002/2017GL074274, 2017.

Magny, M., Vannière, B., de Beaulieu, J.-L., Bégeot, C., Heiri, O., Millet, L., Peyron, O., and Walter-Simonnet, A.-V.: Early-Holocene climatic oscillations recorded by lake-level fluctuations in west-central Europe and in central Italy, Quaternary Sci. Rev., 26, 1951-1964, https://doi.org/10.1016/j.quascirev.2006.04.013, 2007.

Martin-Puertas, C., Brauer, A., Dulski, P., and Brademann, B.: Testing climate-proxy stationarity throughout the Holocene: an example from the varved sediments of Lake Meerfelder Maar (Germany), Quaternary Sci. Rev., 58, 56-65, https://doi.org/10.1016/j.quascirev.2012.10.023, 2012a.

Martin-Puertas, C., Matthes, K., Brauer, A., Muscheler, R., Hansen, F., Petrick, C., Aldahan, A., Possnert, G., and van Geel, B.: Regional atmospheric circulation shifts induced by a grand solar minimum, Nat. Geosci., 5, 397-401, https://doi.org/10.1038/ngeo1460, 2012b.

Martin-Puertas, C., Tjallingii, R., Bloemsma, M., and Brauer, A.: Varved sediment responses to early Holocene climate and environmental changes in Lake Meerfelder Maar (Germany) obtained from multivariate analyses of micro X-ray fluorescence core scanning data, J. Quaternary Sci., 32, 427-436, https://doi.org/10.1002/jqs.2935, 2017.

Masson-Delmotte, V., Landais, A., Stievenard, M., Cattani, O., Falourd, S., Jouzel, J., Johnsen, S. J., Dahl-Jensen, D., Sveinsbjornsdottir, A., White, J. W. C., Popp, T., and Fischer, H.: Holocene climatic changes in Greenland: Different deuterium excess signals at Greenland Ice Core Project (GRIP) and NorthGRIP, J. Geophys. Res., 110, D14102, https://doi.org/10.1029/2004JD005575, 2005. 
Matthes, K., Kuroda, Y., Kodera, K., and Langematz, U.: Transfer of the solar signal from the stratosphere to the troposphere: Northern winter, J. Geophys. Res., 111, D06108, https://doi.org/10.1029/2005JD006283, 2006.

McCarthy, G. D., Haigh, I. D., Hirschi, J. J. M., Grist, J. P., and Smeed, D. A.: Ocean impact on decadal Atlantic climate variability revealed by sea-level observations, Nature, 521, 508-510, https://doi.org/10.1038/nature14491, 2015.

Mekhaldi, F.: ${ }^{10} \mathrm{Be}$ concentrations from lake Meerfelder Maar during the earliest part of the Holocene, PANGAEA, https://doi.org/10.1594/PANGAEA.907808, 2019.

Merz, N., Raible, C. C., and Woollings, T.: North Atlantic Eddy-Driven Jet in Interglacial and Glacial Winter Climates, J. Climate, 28, 3977-3997, https://doi.org/10.1175/JCLI-D-14$00525.1,2015$.

Moffa-Sánchez, P., Born, A., Hall, I. R., Thornalley, D. J. R., and Barker, S.: Solar forcing of North Atlantic surface temperature and salinity over the past millennium, Nat. Geosci., 7, 275-278, https://doi.org/10.1038/ngeo2094, 2014.

Muscheler, R., Beer, J., Wagner, G., Laj, C., Kissel, C., Raisbeck, G. M., Yiou, F., and Kubik, P. W.: Changes in the carbon cycle during the last deglaciation as indicated by the comparison of ${ }^{10} \mathrm{Be}$ and ${ }^{14} \mathrm{C}$ records, Earth Planet. Sci. Lett., 219, 325-340, https://doi.org/10.1016/S0012-821X(03)00722-2, 2004.

Muscheler, R., Kromer, B., Björck, S., Svensson, A., Friedrich, M., Kaiser, K. F., and Southon, J.: Tree rings and ice cores reveal ${ }^{14} \mathrm{C}$ calibration uncertainties during the Younger Dryas, Nat. Geosci., 1, 263-267, https://doi.org/10.1038/ngeo128, 2008.

Muscheler, R., Adolphi, F., and Knudsen, M. F.: Assessing the differences between the IntCal and Greenland ice-core time scales for the last 14,000 years via the common cosmogenic radionuclide variations, Quaternary Sci. Rev., 106, 81-87, https://doi.org/10.1016/j.quascirev.2014.08.017, 2014.

Ortega, P., Lehner, F., Swingedouw, D., Masson-Delmotte, V., Raible, C. C., Casado, M., and Yiou, P.: A model-tested North Atlantic Oscillation reconstruction for the past millennium, Nature, 523, 71-74, https://doi.org/10.1038/nature14518, 2015.

Pedro, J. B., Mcconnell, J. R., Van Ommen, T. D., Fink, D., Curran, M. A. J., Smith, A. M., Simon, K. J., Moy, A. D., and Das, S. B.: Solar and climate influences on ice core ${ }^{10} \mathrm{Be}$ records from Antarctica and Greenland during the neutron monitor era, Earth Planet. Sc. Lett., 355-356, 174-186, https://doi.org/10.1016/j.eps1.2012.08.038, 2012.

Rach, O., Brauer, A., Wilkes, H., and Sachse, D.: Delayed hydrological response to Greenland cooling at the onset of the Younger Dryas in western Europe, Nat. Geosci., 7, 109-112, https://doi.org/10.1038/ngeo2053, 2014.

Rasmussen, S. O., Andersen, K. K., Svensson, A. M., Steffensen, J. P., Vinther, B. M., Clausen, H. B., Siggaard-Andersen, M.L., Johnsen, S. J., Larsen, L. B., Dahl-Jensen, D., Bigler, M., Röthlisberger, R., Fischer, H., Goto-Azuma, K., Hansson, M. E., and Ruth, U.: A new Greenland ice core chronology for the last glacial termination, J. Geophys. Res., 111, D06102, https://doi.org/10.1029/2005JD006079, 2006.

Rasmussen, S. O., Vinther, B. M., Clausen, H. B., and Andersen, K. K.: Early Holocene climate oscillations recorded in three Greenland ice cores, Quaternary Sci. Rev., 26, 1907-1914, https://doi.org/10.1016/j.quascirev.2007.06.015, 2007.
Rasmussen, S. O., Bigler, M., Blockley, S. P., Blunier, T., Buchardt, S. L., Clausen, H. B., Cvijanovic, I., Dahl-Jensen, D., Johnsen, S. J., Fischer, H., Gkinis, V., Guillevic, M., Hoek, W. Z., Lowe, J. J., Pedro, J. B., Popp, T., Seierstad, I. K., Steffensen, J. P., Svensson, A. M., Vallelonga, P., Vinther, B. M., Walker, M. J. C., Wheatley, J. J., and Winstrup, M.: A stratigraphic framework for abrupt climatic changes during the Last Glacial period based on three synchronized Greenland ice-core records: refining and extending the INTIMATE event stratigraphy, Quaternary Sci. Rev., 106, 14-28, https://doi.org/10.1016/j.quascirev.2014.09.007, 2014.

Reimer, P. J., Bard, E., Bayliss, A., Beck, J. W., Blackwell, P. G., Ramsey, C. B., Buck, C. E., Cheng, H., Edwards, R. L., Friedrich, M., Grootes, P. M., Guilderson, T. P., Haflidason, H., Hajdas, I., Hatté, C., Heaton, T. J., Hoffmann, D. L., Hogg, A. G., Hughen, K. A., Kaiser, K. F., Kromer, B., Manning, S. W., Niu, M., Reimer, R. W., Richards, D. A., Scott, E. M., Southon, J. R., Staff, R. A., Turney, C. S. M., and van der Plicht, J.: IntCal13 and Marine13 Radiocarbon Age Calibration Curves 0-50,000 Years cal BP, Radiocarbon, 55, 1869-1887, https://doi.org/10.2458/azu_js_rc.55.16947, 2013.

Seierstad, I. K., Abbott, P. M., Bigler, M., Blunier, T., Bourne, A. J., Brook, E., Buchardt, S. L., Buizert, C., Clausen, H. B., Cook, E., Dahl-Jensen, D., Davies, S. M., Guillevic, M., Johnsen, S. J., Pedersen, D. S., Popp, T. J., Rasmussen, S. O., Severinghaus, J. P., Svensson, A., and Vinther, B. M.: Consistently dated records from the Greenland GRIP, GISP2 and NGRIP ice cores for the past 104 ka reveal regional millennial-scale $\delta^{18} \mathrm{O}$ gradients with possible Heinrich event imprint, Quaternary Sci. Rev., 106, 2946, https://doi.org/10.1016/j.quascirev.2014.10.032, 2014.

Simpson, I. R., Blackburn, M., Haigh, J. D., Simpson, I. R., Blackburn, M., and Haigh, J. D.: The Role of Eddies in Driving the Tropospheric Response to Stratospheric Heating Perturbations, J. Atmos. Sci., 66, 1347-1365, https://doi.org/10.1175/2008jas2758.1, 2009.

Sjolte, J., Sturm, C., Adolphi, F., Vinther, B. M., Werner, M., Lohmann, G., and Muscheler, R.: Solar and volcanic forcing of North Atlantic climate inferred from a process-based reconstruction, Clim. Past, 14, 1179-1194, https://doi.org/10.5194/cp-141179-2018, 2018.

Southon, J.: A First Step to Reconciling the GRIP and GISP2 IceCore Chronologies, 0-14,500 yr B.P., Quaternary Res., 57, 3237, https://doi.org/10.1006/qres.2001.2295, 2002.

Steig, E. J., Grootes, P. M., and Stuiver, M.: Seasonal Precipitation Timing and Ice Core Records. Science, 266, 1885-1886, https://doi.org/10.1126/science.266.5192.1885, 1994.

Stroeven, A. P., Hättestrand, C., Kleman, J., Heyman, J., Fabel, D., Fredin, O., Goodfellow, B. W., Harbor, J. M., Jansen, J. D., Olsen, L., Caffee, M. W., Fink, D., Lundqvist, J., Rosqvist, G. C., Strömberg, B., and Jansson, K. N.: Deglaciation of Fennoscandia, Quaternary Sci. Rev., 147, 91-121, https://doi.org/10.1016/j.quascirev.2015.09.016, 2016.

Stuiver, M. and Polach, H. A.: Discussion Reporting of ${ }^{14} \mathrm{C}$ Data, Radiocarbon, 19, 355-363, https://doi.org/10.1017/S0033822200003672, 1977.

Svalgaard, L. and Schatten, K. H.: Reconstruction of the Sunspot Group Number: The Backbone Method, Sol. Phys., 291, 26532684, https://doi.org/10.1007/s11207-015-0815-8, 2016.

Svensson, A., Andersen, K. K., Bigler, M., Clausen, H. B., DahlJensen, D., Davies, S. M., Johnsen, S. J., Muscheler, R., Par- 
renin, F., Rasmussen, S. O., Röthlisberger, R., Seierstad, I., Steffensen, J. P., and Vinther, B. M.: A 60000 year Greenland stratigraphic ice core chronology, Clim. Past, 4, 47-57, https://doi.org/10.5194/cp-4-47-2008, 2008.

van der Plicht, J., van Geel, B., Bohncke, S. J. P., Bos, J. A. A., Blaauw, M., Speranza, A. O. M., Muscheler, R., and Björck, S.: The Preboreal climate reversal and a subsequent solar-forced climate shift, J. Quaternary Sci., 19, 263-269, https://doi.org/10.1002/jqs.835, 2004.

Vinther, B. M., Clausen, H. B., Johnsen, S. J., Rasmussen, S. O., Andersen, K. K., Buchardt, S. L., Dahl-Jensen, D., Seierstad, I. K., Siggaard-Andersen, M.-L., Steffensen, J. P., Svensson, A., Olsen, J., and Heinemeier, J.: A synchronized dating of three Greenland ice cores throughout the Holocene, J. Geophys. Res., 111, D13102, https://doi.org/10.1029/2005JD006921, 2006.

Vinther, B. M., Buchardt, S. L., Clausen, H. B., Dahl-Jensen, D., Johnsen, S. J., Fisher, D. A., Koerner, R. M., Raynaud, D., Lipenkov, V., Andersen, K. K., Blunier, T., Rasmussen, S. O., Steffensen, J. P., and Svensson, A. M.: Holocene thinning of the Greenland ice sheet, Nature, 461, 385-388, https://doi.org/10.1038/nature08355, 2009. von Grafenstein U., Erlenkeuser, H., Brauer, A., Jouzel, J., and Johnsen, S. J.: A mid-european decadal isotope-climate record from 15,500 to 5000 years B.P., Science, 284, 1654-1657, https://doi.org/10.1126/science.284.5420.1654, 1999.

Vonmoos, M., Beer, J., and Muscheler, R.: Large variations in Holocene solar activity: Constraints from ${ }^{10} \mathrm{Be}$ in the Greenland Ice Core Project ice core, J. Geophys. Res., 111, A10105, https://doi.org/10.1029/2005JA011500, 2006.

White, J. W. C., Barlow, L. K., Fisher, D., Grootes, P. M., Jouzel, J., Johnsen, S. J., Stuiver, M., and Clausen, H. B.: Stable isotope stacks from GRIP and GISP ice cores, PANGAEA, https://doi.org/10.1594/PANGAEA.716878, 2009.

Woollings, T., Lockwood, M., Masato, G., Bell, C., and Gray, L.: Enhanced signature of solar variability in Eurasian winter climate, Geophys. Res. Lett., 37, L20805, https://doi.org/10.1029/2010GL044601, 2010. 